\title{
PELATIHAN SENI PERAN (AKTING) TEATER MONOLOG BAGI SISWA-SISWI DALAM MEMPERSIAPKAN KEGIATANFLS2N
}

\author{
Yalesvita \\ Meria Eliza \\ Saaduddin \\ Prodi Seni Teater Fakultas Seni Pertunjukan \\ Institut Seni Indonesia Padangpanjang \\ Jl. Bahder Johan, Guguak Malintang, Padangpanjang, Kota Padangpanjang, 27126. \\ Sumatera Barat. Indonesia \\ yalesvitaasahan@gmail.com \\ meriaelizaisipp19@gmail.com \\ hanyadidin@gmail.com
}

\begin{abstract}
ABSTRAK
Program Pengabdian Masyarakat ini bertujuan untuk membuka ruang, pengetahuan dan pembinaan bagi generasi muda (siswa-i ) SMUN 01 Batusangkar dalam mempersiapkan diri mengikuti program FLS2N di bidang seni khususnya bidang Monolog. Selain itu pengabdian ini akan menjadi wadah bagi siswa-i menyiapkan portofolio. Pengabdian masyarakat yang akan dilakukan ini, dimaksudkan memberi pelatihan bagi siswa-siswi dalam mengasah bakat dan minat trampil bermonolog, bagaimana menuturkan berbagai pilihan cerita dalam naskah. Pelatihan diawali dengan teknik/latihan dasar, metoda pelatihan bagi siswa-i dalam memerankan/menampilkan karakter. Latihan dasar berupa latihan gesture, emosional, vokal (komunikasi) dan kecerdasan intelektual. Kemudian pelatihan akan dilanjutkan tentang pelatihan pemahaman terhadap naskah dan teknik menyampaikan/ mengkomunikasikan, dan terakhir pelatihan penguasan ruang, karakter dan penonton
\end{abstract}

Kata Kunci: Pembinaan; Monolog; Metode; FLS2N 
PENDAHULUAN

Monolog merupakan suatu bentuk pertunjukan teater yang menampilkan totalitas aktor di atas panggung. Monolog adalah berbicara sendiri dan lawannya ialah dialog. Monolog juga suara hati yang diucapkan, dan seyogyanya bisa didengar oleh penonton dari bangku yang paling depan sampai bangku yang paling belakang di gedung pertunjukan (Marciano, Roci, 2019). Monolog telah berkembang sejak zaman Yunani, Monolog merupakan ilmu terapan yang mempelajari tentang seni Peran, dimainkan oleh satu orang aktor dengan memerankan satu karakter tokoh atau lebih dalam menyampaikan cerita dalam naskah. Monolog disampaikan dalam bentuk komunikasi aktor kepada penonton. Dalam memerankan naskah monolog, aktor dituntut untuk memahani tentang ilmu seni berperan dan juga pelatihan dalam berperan; mamahami naskah yang akan dimainkan, memahami karakter yang akan diperankan, melatih vokal (artikulasi, diksi, intonasi dll), melatih emosi (kemarahan, kesedihan, kebahagiaan dll), melatih tubuh/gestur (ekpresi, mimik, kelenturan dll). Dengan pengetahuan dan pelatihan yang dilakukan ini, memudahkan bagi seorang siswa/i dalam bermonolog di panggung atau di hadapan penonton.
Monolog adalah salah satu pertunjukan teater akan isyarat dalam bentuk ungkapan kata, ekspresi wajah atau gerak tubuh, dan berbagai muatan emosi. Jenis pertunjukan ini telah dikenal sejak zaman yunani. yang sering digunakan dalam ritus keagamaan dengan cerita umumnya sekitar mitologi yunani. Monolog kembali populer pada sekitar tahun 60-an. Pada tahun 1964 monolog diperkenalkan di Hollywood lalu berkembang menjadi sarana seni dan teater dan bahkan menjadi salah satu teori/pembelajaran dari karya seni teater.

Perkembangan monolog di Indonesia pada 5 tahun terakhir ini sangat pesat, banyak minat dari siswa-siswa SMU/SMK bahkan mahasiswa menggemari bentuk kesenian monolog ini, bahkan menjadi kesenian yang populer di kalangan generasi muda. Selain itu banyak lomba yang dilakukan oleh pemerintah daerah maupun pusat terkait dengan pertunjukan monolog ini, salah satunya adalah kegiatan FLS2N. Kegiatan FLS2N ini merupakan program pemerintah dan merupakan wahana untuk ketrampilan bagi siswa-siswi perwakilan dari seluruh Nusantara. Dengan seni akan mengungkapkan beragam rasa, karsa, naluri pikiran yang semuanya berpusat pada nilai estetis dan perpaduan inovasi, disertai dengan ungkapan rasa dan emosi yang sangat mendalam. 


\section{Jurnal Batoboh, Vol 5, No 2, Oktober 2020 \\ Yalesvita, Meria Eliza, Saaduddin}

Berdasarkan penjelasan dan pemahaman ini, sangat perlu dan penting bagi lembaga seni untuk turut andil dan bertanggung jawab membuka ruang, memberi pemahaman keilmuan dan pelatihan bagi generasi muda (mahasiwa-i ) untuk mempersiapkan diri mengikuti program FLS2N di bidang seni khususnya bidang Monolog. Pengabdian masyarakat yang akan dilakukan ini, dimaksudkan memberi pelatihan bagi mahasiswa/mahasiswi SMU 1 Sumbar yang akan difokuskan pada pelatihan akting monolog. Adapun pelatihan monolog sebagai bagian pelatihan dasar teater tersebut sejalan dengan tujuan yang dijelaskan oleh Sari Yunis bahwa pelatihan dasar teater yang bertujuan agar siswa mampu menggunakan vokal, intonasi, artikulasi, mimik (gerak tubuh), serta mampu memberikan interpretasi/ penjiwaan yang tepat terhadap puisi yang dibacakan. Dalam konteks ini terhadap medium teater memiliki relasi terhadap medium puisi yang diujicobakan oleh Sari Yunis tersebut (Yunis et al., 2015). Pelatihan akan dimulai dari latihan dasar yakni; latihan gesture, emosional, vokal (komunikasi) dan kecerdasan. Kemudian pelatihan akan dilanjutkan tentang pelatihan pemahaman terhadap naskah dan teknik menyampaikan /mengkomunikasikan, dan terakhir pelatihan penguasaan ruang, karakter dan penonton. Dalam hal ini Metode Drill juga digunakan. Enrico Alamo menyatakan bahwa metode ini yaitu suatu metode yang diberikan kepada anggota/peserta agar materi yang sudah diajarkan diulang di rumah, sehingga anggota atau peserta menguasai penampilan cerita yang telah diajarkan secara baik dan benar (Alamo et al., 2018). Setelah melalui beberapa tahapan latihan ini, dengan harapan siswa/siswi telah siap memainkan naskah monolog dan siap mengikuti kompetisi dalam program FLS2N. Program pengabdian masyarakat ini dilakukan selain bertujuan melatih dan membina siswa/siswi dalam seni monolog juga ikut serta membantu dan mendukung program pemeritah dalam kegiatan FLS2N.

Dalam hal ini sebelum dilakukan pelaksanaan kegiatan, maka dilakukan terhadap studi kepustakaan. Hal ini untuk menelaah sumber yang ada relevansinya dengan tugas pelaksanaan pengabdian yang dilakukan. Di samping itu, telaah kepustakaan mempunyai arti yang signifikan untuk mendapatkan konsep-konsep, teoriteori atau dalil-dalil tertentu yang dapat digunakan sebagai pedoman untuk melakukan pelatihan dan pembinaan teater monolog melalui latihan akting. Hal yang paling mendasar yang dilakukan dalam proses kreatif teater salah satunya latihan 


\section{Jurnal Batoboh, Vol 5, No 2, Oktober 2020 \\ Yalesvita, Meria Eliza, Saaduddin}

dasar akting. Banyak orang pada kelompokkelompok kesenian melakukan pelatihan dasar akting dengan metode dan caranya masing-masing, tetapi lebih bersifat improvisasi. Yang terkadang tidak menggunakan teknik dan cara yang terstruktur. Sehingga banyak dari anggota yang menerima materi, tidak merasakan manfaat dari materi yang telah diberikan untuk kebutuhan akting sewaktu mereka memerankan karakter sesuai tuntutan naskah/sutradaranya. Berdasarkan fenomena ini, materi yang akan diberikan pada pelatihan ini berangkat dari pengolahan kemampuan individu dari peserta. Sehingga pada akhirnya individu ini dapat mengaplikasikan kemampuan dan kekuatan individu mereka.

Akting (peran) berasal dari kata "to $a c t$ " yang berarti "beraksi”. Ating dalam konteks ini adalah perpaduan antara atraksi fisikal (kebertubuhan), intelektual (analisis karakter dan naskah) dan spiritual (transformasi jiwa). Usaha seorang aktor dalam melakoni seni akting adalah mengembangkan kemampuan berekspresi, menganalisis naskah dan mentransformasi diri ke dalam karakter yang ia mainkan. Dengan menempa kemampuan ketiganya, aktor akan bisa membuka diri dan menyerap kekayaan pegalaman hidup dari si tokoh sesuai dengan konsep penulis naskah atau sutradara (Rikrik ES, 2006:3).

Kegiatan pelatihan dasar-dasar akting kali ini, tidak saja dilakukan secara teoritik -penjelasan lisan dan diskusi-, tetapi Hal| 90 juga langsung mempraktekkannya dengan seluruh peserta yang mengikuti program ini. Tahapan ini menjadi tolak ukur keberhasilan yang akan dicapai dari pelatihan tersebut.

\section{PEMBAHASAN}

Aktor merupakan subjek terpenting dalam pertunjukan teater, karena ia juga salah satu motor dalam sebuah pertunjukan teater. Aktor adalah orang yang akan mengaplikasikan penafsirannya dengan baik dan menyampaikannya kepada penonton dengan bahasa verbal ataupun non-verbal. Seorang aktor perlu persiapan yang matang dan prima untuk menunjang keaktorannya di atas panggung dan sukses melaksanakan pekerjaannya. Pertunjukan yang berlangsung dan pekerjaan aktor ketika berada di atas panggung akan berjalan dengan lancar. Sitorus (2002: 16) mengatakan dalam bukunya The Art Of Acting bahwa:

"Peran aktor dalam dunia teater semakin penting sejak seni drama mengalami proses tranformasi selama ini. Di zaman Yunani kuno, kemampuan individu terbenam dikerumunan koor yang memenuhi 


\section{Jurnal Batoboh, Vol 5, No 2, Oktober 2020 \\ Yalesvita, Meria Eliza, Saaduddin}

panggung. Tetapi tahap demi tahap, seni drama mulai menganalisa jiwa manusia, meneliti sifat-sifat asmara, cinta kebencian, balas dendam, kesedihan dan lainnya. Seni keaktoran berkembang, sehingga semakin kompleks dan tidak mudah dilakukan oleh sembarang orang saja. Profesi keaktoran sekarang menjadi profesi yang khusus, sehingga tugas seorang aktor adalah sulit dan menguras tenaga. Peran tersebut membuat seorang aktor menjadi ujung tombak sebuah pertunjukan".

\section{Solusi Yang Direalisasikan}

Dalam teater monolog ada beberapa metode yang harus dilakukan guna mempersiapkan aktor. Metode ini terdiri dari beberapa tahapan

\section{Aktor dan inteligensia}

Aktor harus lah orang yang memiliki intelektual dan pemikiran yang luas. Artinya aktor adalah orang yang cerdas. Yang peka terhadap persoalan sosial, politik, ekonomi dan sejarah. Untuk itu aktor harus berlatih membaca, baik membaca berbagai buku maupun membaca fenomena yang telah belasung, sedang berlansung maupun akan berlansung. Sehingga aktor menjadi orang yang peka terhadap berbagai persoalan dalam kehidupan dan akan mampu menganalisa dan tafsir terhadap naskah monolog. Untuk itu aktor harus melatih inteligensia

\section{Aktor dan raganya/jiwa}

Seorang aktor harus mampu menjadi karakter baik secara fisikal maupun secara emosional. Oleh karenanya aktor harus memiliki tubuh yang siap dan lentur. Yang Hal| 91 mampu mengekspresikan berbagai emosi. Untuk itu seorang aktor harus melatih tubuh (fisik) agar lentur dan melatih rasa/emosi agar mampu berekspresi secara total.

\section{Aktor dan Vokalnya}

Dalam monolog, vokal merupakan unsur utama dalam menyampaikan cerita dalam naskah. Untuk itu seorang aktor dituntut untuk memiliki vokal yang keras dan jelas. Oleh karenanya aktor harus melatih artikulasi, diksi, intonasi, nada, irama, tempo dan dinamika. Aktor juga harus melatih pernapasan (pernapasan dada, perut dan diafragma).

\section{Bentuk Latihan Yang Diterapkan}

\section{a. Relaksasi}

Relaksasi di sini berarti suatu keadaan dimana penyaji berada pada posisi siap untuk memberikan reaksi pada stimulus terkecil. Latihan ini dilakukan dengan beberapa gerak pada tubuh, seperti menggerakkan tangan, kaki, dan muka. Begitu juga dengan suara, untuk memperjelas dialog yang akan disampaikan. Latihan ini dilakukan sebelum memulai proses latihan. 


\section{Jurnal Batoboh, Vol 5, No 2, Oktober 2020 \\ Yalesvita, Meria Eliza, Saaduddin}

\section{b. Konsentrasi}

Konsentrasi dalam memainkan peran di atas panggung, penyaji membutuhkan konsentrasi terhadap perannya. Konsentrasi yang meliputi dialog dengan lawan main. Hal ini untuk mendapatkan akting spontanitas yang natural.

Konsentrasi merupakan pemusatan pikiran atau perhatian. Makin menarik pusat perhatian, makin tinggi kesanggupan memusatkan perhatian. Pusat perhatian seorang pemeran adalah sukma atau jiwa peran atau karakter yang akan dimainkan. Segala sesuatu yang mengalihkan perhatian seorang pemeran, cenderung dapat merusak proses pemeranan. Maka, konsentrasi menjadi sesuatu hal yang penting untuk pemeran. Tujuan dari konsentrasi ini adalah untuk mencapai kondisi kontrol mental maupun fisik di atas panggung. Ada korelasi yang sangat dekat antara pikiran dan tubuh. Seorang pemeran harus dapat mengontrol tubuhnya setiap saat. Langkah awal yang perlu diperhatikan adalah mengasah kesadaran dan mampu menggunakan tubuhnya dengan efisien. Dengan konsentrasi pemeran akan dapat mengubah dirinya menjadi orang lain, yaitu peran yang dimainkan.

Dunia teater adalah dunia imajiner atau dunia rekaan. Dunia tidak nyata yang diciptakan seorang penulis lakon dan diwujudkan oleh pekerja teater. Dunia ini harus diwujudkan menjadi sesuatu yang seolah-olah nyata dan dapat dinikmati serta meyakinkan penonton. Kekuatan pemeran untuk mewujudkan dunia rekaan ini hanya bias dilakukan dengan kekuatan daya konsentrasi. Misalnya seorang pemeran melihat sesuatu yang menjijikan (meskipun sesuatu itu tidak ada di atas pentas) maka ia harus menyakinkan kepada penonton bahwa sesuatu yang dilihat benar-benar menjijikkan. Kalau pemeran dengan tingkat konsentrasi yang rendah maka dia tidak akan dapat menyakinkan penonton.

\section{c. Observasi}

Observasi sangat diperlukan untuk menjiwai suatu peran, apa lagi peran yang dimainkan tidak sesuai dengan keseharian peyaji. Maka aktor melakukan observasi dengan mengamati kehidupan tertentu dalam masyarakat yang memiliki kemiripan dengan tokoh.

\section{Materi- Materi Latihan}

\section{A. Olah Rasa}

Pemeran teater membutuhkan kepekaan rasa. Dalam menghayati karakter peran, semua emosi tokoh yang diperankan harus mampu diwujudkan. Oleh karena itu, latihan-latihan yang mendukung kepekaan rasa perlu dilakukan. Terlebih dalam konteks aksi dan reaksi. Seorang pemeran 


\section{Jurnal Batoboh, Vol 5, No 2, Oktober 2020 \\ Yalesvita, Meria Eliza, Saaduddin}

tidak hanya memikirkan ekspresi karakter tokoh yang diperankan saja, tetapi juga harus memberikan respon terhadap ekspresi tokoh lain. Banyak pemeran yang hanya mementingkan ekspresi yang diperankan sehingga dalam benaknya hanya melakukan aksi. Padahal akting adalah kerja aksi dan reaksi. Seorang pemeran yang hanya melakukan aksi berarti baru mengerjakan separuh dari tugasnya. Tugas yang lain adalah memberikan reaksi (Mary Mc Tigue, 1992). Dengan demikian, latihan olah rasa tidak hanya berfungsi untuk meningkatkan kepekaan rasa dalam diri sendiri, tetapi juga perasaan terhadap karakter lawan main. Latihan olah rasa dimulai dari konsentrasi, mempelajari gesture, dan imajinasi.

\section{B. Gesture}

Gesture merupakan sikap atau pose tubuh pemeran yang mengandung makna. Latihan gesture dapat digunakan untuk mempelajari dan melahirkan bahasa tubuh. Ada juga yang mengatakan bahwa gesture merupakan bentuk komunikasi non verbal yang diciptakan oleh bagian-bagian tubuh yang dapat dikombinasikan dengan bahasa verbal. Bahasa tubuh dilakukan oleh seseorang terkadang tanpa disadari dan keluar mendahului bahasa verbal. Bahasa ini mendukung dan berpengaruh dalam proses komunikasi. Jika berlawanan dengan bahasa verbal akan mengurangi kekuatan komunikasi, sedangkan kalau selaras dengan bahasa verbal akan menguatkan proses komunikasi. Seorang pemeran harus memahami bahasa tubuh, baik bahasa tubuh budaya sendiri maupun bahasa tubuh budaya lainnya. Pemakaian gesture ini mengajak seseorang untuk menampilkan variasi bahasa atau bermacam-macam cara mengungkapkan perasaan dan pemikiran. Akan tetapi, gesture tidak dapat menggantikan bahasa verbal sepenuhnya. Sedang beberapa orang menggunakan gesture sebagai tambahan dalam kata-kata ketika melakukan proses komunikasi. Manfaat mempelajari dan melatih gesture adalah mengerti apa yang tidak terkatakan dan yang ada dalam pikiran lawan bicara.

Selain itu, dengan mempelajari bahasa tubuh, akan diketahui tanda kebohongan atau tanda-tanda kebosanan pada proses komunikasi yang sedang berlangsung. Bahasa tubuh semacam respon atau impuls dalam batin seseorang yang keluar tanpa disadari. Sebagai seorang pemeran, gesture harus disadari dan diciptakan sebagai penguat komunikasi dengan bahasa verbal. Sifat bahasa tubuh adalah tidak universal. Misalnya, orang India, mengangguk tandanya tidak setuju sedangkan menggeleng artinya setuju. Hal ini berlawanan dengan bangsa-bangsa lain. Tangan mengacung dengan jari telunjuk dan 


\section{Jurnal Batoboh, Vol 5, No 2, Oktober 2020 \\ Yalesvita, Meria Eliza, Saaduddin}

jempol membentuk lingkaran, bagi orang perancis artinya nol, bagi orang Yunani berarti penghinaan, tetapi bagi orang Amerika artinya bagus. Jadi bahasa tubuh harus dipahami oleh pemeran sebagai pendukung bahasa verbal.

Macam-macam gesture yang dapat dipahami orang lain adalah gesture dengan tangan, gesture dengan badan, gesture dengan kepala dan wajah, dan gesture dengan kaki. Bahasa tubuh atau gesture dengan tangan adalah bahasa tubuh yang tercipta oleh posisi maupun gerak kedua tangan. Bahasa tubuh yang tercipta oleh kedua tangan merupakan bahasa tubuh yang paling banyak jenisnya. Bahasa tubuh dengan tubuh adalah bahasa tubuh yang tercipta oleh pose atau sikap tubuh seseorang. Bahasa tubuh dengan kepala dan wajah adalah bahasa tubuh yang tercipta oleh posisi kepala maupun ekspresi wajah. Sedangkan bahasa tubuh dengan kaki adalah bahasa tubuh yang tercipta oleh posisi dan bagaimana meletakkan kaki.

\section{Teknik Dasar Pemeranan}

Teknik dasar pemeran adalah teknik mendayagunakan peralatan ekspresi pemeran. Fungsi teknik dasar adalah untuk meningkatkan keluwesan dan ketahanan tubuh, serta keterampilan gerak, dan reaksi. Latihan teknik dasar pemeranan ini merupakan landasan kuat untuk bangunan penciptaan peran. Latihan harus dilakukan terus menerus, diresapi, dan dikuasai sampai menjadi hal yang bukan teknis. Latihan nonteknis adalah latihan penguasaan tubuh dan jiwa pemeran itu sendiri seperti rileksasi, konsentrasi, kepekaan, kreativitas yang terpusat pada pikirannya. Sedangkan latihan yang bersifat teknis adalah latihan yang terfokus pada latihan penguasaan peran yang akan dimainkan. Latihan teknik ini penting dilakukan oleh pemeran, karena dalam menjalankan tugasnya ia harus terampil menggunakan segala aspek yang diperlukan saat memainkan karakter. Semakin terampil ia memainkan karakter, maka penonton semakin mengerti dan mau menerima permainan itu. Latihan teknik ini harus dipelajari dan dikuasai, tetapi ketika teknikteknik ini sudah terkuasai maka harus lebur menjadi milik pribadi pemeran. Teknikteknik itu harus menjadi sesuatu yang spontan ketika digunakan. Latihan teknik bermain ada dua macam yaitu latihan teknik yang bersifat individu dan latihan teknik yang bersifat umum.

Teknik yang bersifat individual diciptakan oleh seorang pemeran dalam menghadapi peran yang akan dimainkan. Misalnya, teknik Yoyok Aryo (Alm.), Jim Carey, Butet Kertarajasa, Arifin C. Noor, Putu Wijaya, dan lain-lain. Teknik ini sangat unik, karena timbul dari pribadi-pribadi 


\section{Jurnal Batoboh, Vol 5, No 2, Oktober 2020 \\ Yalesvita, Meria Eliza, Saaduddin}

seniman. Orang lain bisa mempelajari teknik yang bersifat individual ini, tetapi kebanyakan akan terjebak dengan peniruan. Teknik latihan yang bersifat umum ini bisa dipelajari dan digunakan secara umum. Bila digunakan akan menghasilkan sesuatu yang umum tetapi ini juga penting dipelajari calon pemeran. Latihan teknik bermain yang digunakan disini adalah latihan teknik yang bersifat umum yang diajarkan oleh W.S. Rendra, latihanlatihan ini terdiri dari teknik muncul, teknik memberi isi, teknik pengembangan, teknik membina puncakpuncak, teknik timing, teknik penonjolan, teknik pengulangan, dan teknik improvisasi.

\section{Proses Menuju Pertunjukan}

\section{a. Pemilihan Naskah}

Naskah akan menjadi pengantar bagi aktor untuk sampai ke sebuah pertunjukan, naskah akan menggiring aktor mengetahui gambaran tokoh yang akan diperankannya dalam sebuah pertunjukan.

Ketertarikan terhadap naskah hendaknya didasarkan atas isu yang ada di dalam naskah ini, Isu yang terdapat didalam naskah ini adalah kehidupan sosial politik dan hukum di Indonesia saat ini yang mengalami krisis kepercayaan dari masyarakatnya. Kemudian dikembangkan melalui konflik-konflik yang diciptakan. Aktor perlu melihat isu yang konteks dengan apa yang terjadi saat ini terhadap kehidupan politik dan hukum. aktor dalam melakukan pemilihan naskah, pertama-tama dengan melihat siapa pengarangnya, dalam hal ini dimaksudkan untuk mencari pengarang yang karya- karyanya diperhitungkan.

\section{Proses Latihan}

Tahap latihan dimulai dengan mengolah vokal, rasa dan tubuh, yang tidak pernah terlepas kaitannya dalam dunia pemeranan. Seterusnya mengaplikasikan pendekatan akting, aktor dapat memerankan sebuah karakter dengan pengalam hidup baik pengalaman hidup diri sendiri maupun pengalam hidup orang-orang di sekelilingnya, lalu pengalaman tersebut ditransformasikan kedalam akting ke atas panggung. Emosi-emosi seperti marah, sedih, rasa haru, dan bahagia, yang pernah penyaji rasakan dan memiliki kesamaan emosi dengan tokoh yang dimainkan, diingat kembali kemudian ditrasformasikan. Begitu juga dengan pengalaman yang dilihat dari orang-orang di sekitar yang memiliki kesamaan dengan tokoh yang akan diperankan dapat ditirukan ke atas panggung. Pengalaman hidup tersebut, menjadi alat dalam memancing perasaan yang harus dilahirkan dalam memerankan tokoh dalam naskah monolog yang telah dipilih. 


\section{Jurnal Batoboh, Vol 5, No 2, Oktober 2020 \\ Yalesvita, Meria Eliza, Saaduddin}

\section{a. Reading}

Tahap reading pertama, penyaji mengumpulkan lawan main lainya dan mulai membaca teks sesuai dengan giliran, tujuannya adalah untuk konsentrasi dalam mengetahui alur cerita. Aktor kemudian mendiskusikan alur cerita sehingga memiliki kesamaan tafsir atas cerita. agar dapat melatih respon tubuh pada teks naskah yang didialogkan. Sekaligus membiasakan gestur tubuh, kemudian Membuat distorsi pada aktingnya.

\section{b. Pengenalan Properti dan Kostum}

Tahap ini dilakukan untuk mengenalkan dan mengakrabkan pada setting dan properti. aktor melakukan pemahaman dan mulai melakukan perkenalan dengan hand property atau properti yang akan dibawakan dalam permainan, misalnya kaca mata, kipas, topeng, tas, kalung, wig dan lain-lain. Sehingga dapat terbiasa dalam menggunakannya dan dapat dieksplorasi sesuai dengan kebutuhan akting. Untuk tahap ini aktor juga mulai mencoba-coba mengenakan kostum yang sesuai hingga sampai ketemu kostum apa yang cocok, agar dapat mengukur kenyamanan dan kesesuaian, yang dapat berpengaruh pada proses permainan.

\section{b. Blocking}

Blocking mengacu pada tata gerak seorang aktor dalam beraksi disebuah adegan. Hal ini memperhitungkan motivasimotivasi yang logis dalam melakukan perpindahan. Tahap ini dilakukan aktor dengan cara memahami dialog satu-persatu, sehingga aktor menemukan kalimat yang memberi kemungkinan untuk dapat berpindah tempat sesuai dengan movemant.

\section{c. Latihan dengan Musik}

Tahap ini aktor latihan diiringi musik, yang membantu dalam mempertegas suasana dan emosi. Pertama, penata musik datang untuk melihat latihan dari awal hingga akhir, agar penata musik dapat mengetahui cerita naskah dari awal hingga akhir kemudian dapat lebih mundah mencari bentuk musik yang sesuai dengan suasana dan mood pertunjukan. Kemudian penata musik latihan tersendiri dengan player lainya untuk mencari bentuk musik yang akan digunakan untuk mengisi suasana. Latihan selanjutnya pemusik menawarkan rancangan musik yang telah dicari, mencobanya dengan sistem latihan cut to cut untuk menyesuaikan dengan mood permainan, sehingga dapat terjalin keselarasan antara musik dan suasana. 


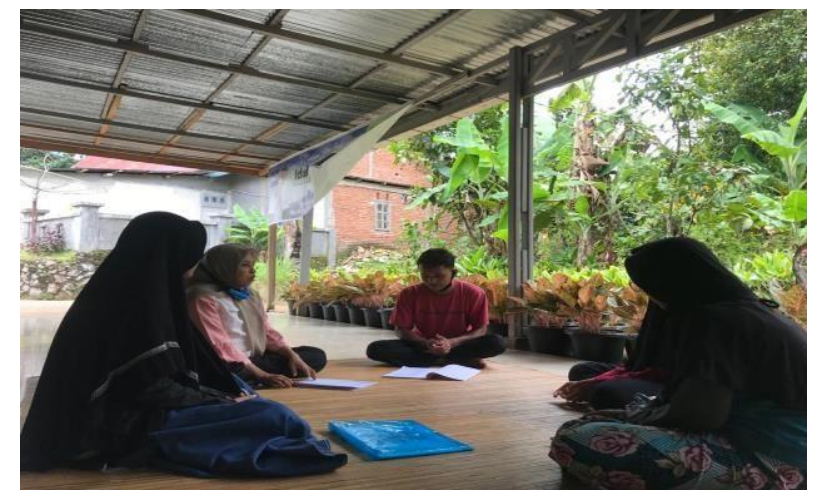

Gambar 1.

Kegiatan latihan Akting

Teater Monolog

(Foto; Meria Eliza, 2020)

Secara konseptual, para peserta telah memiliki pengetahuan dan pemahaman tentang proses kerja teater monolog melalui proses pelatihan dasar akting

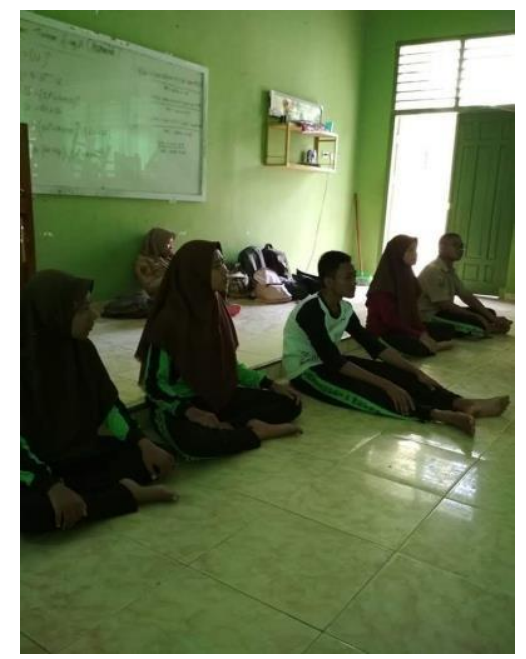

Gambar 2.

Kegiatan latihan Akting

Teater Monolog

(Foto; Meria Eliza, 2020)

Peserta pelatihan dapat memahami, mempraktekkan dan melatih tubuh mereka dengan cara pemanasan, kelenturan dan keseimbangan yang baik sesuai dengan teknik yang diajarkan. hal ini digunakan pada saat mereka melahirkan secara visual karakteristik tubuh tokoh yang mereka perankan

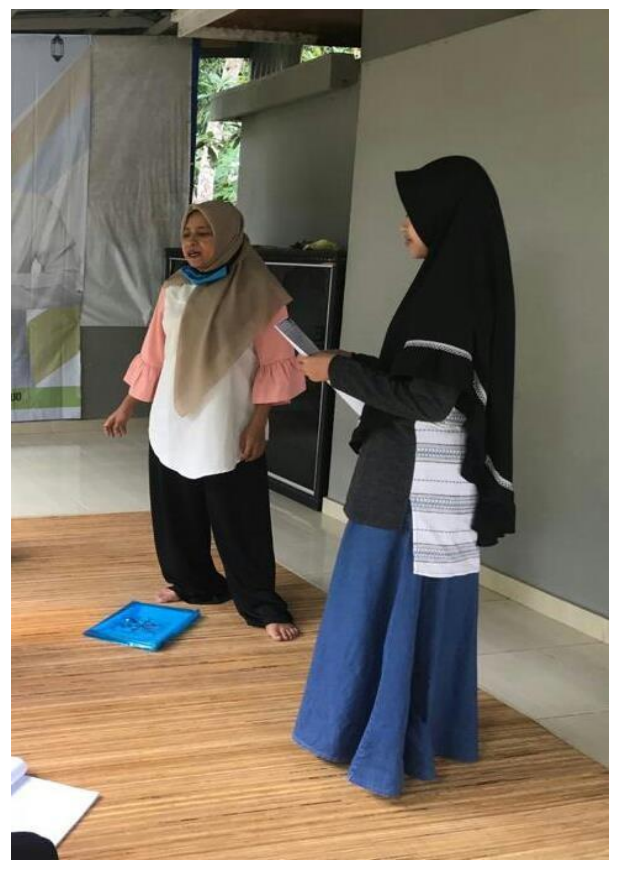

Gambar 3.

Kegiatan latihan Akting

Teater Monolog

(Foto; Meria Eliza, 2020)

Peserta pelatihan dapat memahami dan menjiwai karakter tokoh yang mereka pahami dari naskah yang telah mereka tentukan. 


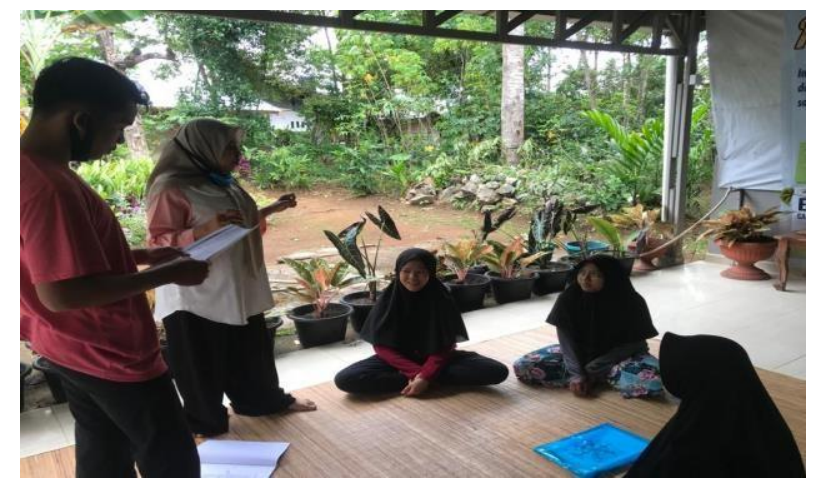

Gambar 4.

Kegiatan latihan Akting

Teater Monolog

(Foto; Meria Eliza, 2020)

memberikan kebebasan untuk menghafal

dialog yang menggambarkan karakter dari

tokoh yang diperankan.

\section{SIMPULAN}

Kegiatan kesenian di SMU 01 Batusangkar merupakan kegiatan dan ekstrakurikuler yang paling banyak diminati oleh siswa-siswi, seperti; seni tari, musik, randai, bahkan seni teater. Kegiatan kesenian bagi siswa merupakan ruang kreatif, inovatif dan ruang untuk mengapresiasikan diri. Kegiatan ini sangat didukung oleh pihak sekolah dan bahkan selalu terlibat untuk mengirimkan siswasiswa dalam berbagai Festival dan lombalomba seni seperti ikut dalam kegiatan FLS2N. Untuk mewujudkan harapan SMUN 01 bisa tampil dan juara dalam berbagai Festival yang diikuti, pihak sekolah melakukan berbagai upaya untuk memotifasi siswa-siswi untuk mempersiapkan diri, dan juga merasa perlu menghadirkan pelatih/orang yang kompeten di bidang seni agar bisa membantuk siswasiswi dalam melatih dan membina persiapan kegiatan Festifal. Dalam hal ini salah satunya persiapan pertunjukan monolog.

Pengabdian ini dilakukan sebagai bentuk pembinaan terhadap generasi teater monolog di SMUN 01 Batusangkar, bagaimana memerankan naskah monolog, aktor dituntut untuk memahami tentang ilmu seni berperan dan juga pelatihan dalam berperan; memahami naskah yang akan dimainkan, memahami karakter yang akan diperankan, melatih fokal ( artikulasi, diksi, intonasi dll), melatih emosi (kemarahan, kesedihan, kebahagiaan dll), melatih tubuh/gestur (ekpresi, mimik, kelenturan dll). Dengan pengetahuan dan pelatihan yang dilakukan ini, memudahkan bagi seorang siswa/i dalam bermonolog di panggung atau di hadapan penonton.

\section{KEPUSTAKAAN}

Alamo, E., Susanti, D., \& Saaduddin, S.

(2018). PELATIHAN KELOMPOK

SANDIWARA DAN

PEMANTAPAN MANAJEMEN

KELOMPOK DI KELURAHAN

GANTING PADANGPANJANG,

SUMATERA BARAT. Batoboh, 
3(1), 37-47.

https://doi.org/10.26887/bt.v3i1.377

Marciano, Roci. (2019). Pengembangan

Teknik Peran Seorang Aktor Untuk

Pementasan Monolog Melalui

Sistem Stanislavski dalam Buku an

Actor Prepares and Building a

Character. JURNAL SATWIKA:

Kajian Ilmu Budaya Dan

Perubahan Sosial, 3(1), 69-86.

https://doi.org/10.22219/SATWIKA

.Vol3.No1.69-86

Yunis, S., Samhati, S., \& Karomani, K.

KEMAMPUAN MEMBACA

PUISI MELALUI PELATIHAN

DASAR TEATER PADA SISWA

KELAS X. $J$ - SIMBOL (Bahasa

Dan Sastra Indonesia), 3(1), Article

1.

http://jurnal.fkip.unila.ac.id/index.p

hp/BINDO/article/view/10006

Ranjabar,Jacopus. 2006. Sistim Sosial Budaya Indonesia. Bogor. Ghalia Indonesia

Saptaria, Rikrik El. Panduan Praktis Akting Untuk Film dan Teater, Jakarta: Rekayasa Sains, 2006.

Sitorus, Eka D. The Art Of Acting: Seni Peran Untuk Teater, Film dan TV, Jakarta: Gramedia Pustaka Utama, 2002.

Stanislavski, Constantin. Membangun Tokoh, Jakarta: Kepustakaan Populer Gramedia, 2008.

Suyatna Anirun, Menjadi Aktor (Pengantar Untuk Seni Peran Untuk Pentas dan Sinema), Bandung 1998 